\title{
Analysis of factors influencing the price of real estate based on interpretative structural model
}

\author{
Jingxin Gao, a , Hong Ren', Yongjie Du", \\ ${ }^{1}$ Faculty of Construction Management and Real Estate of Chongqing University, Chongqing, \\ China \\ agixin25@163.com
}

Keywords: residential prices; intricate relationships; hierarchical relationship; Interpretive Structure Model

Abstract. Housing is an indispensable material basis for people's lives and its prices also have an important influence on people's lives. Housing price is affected by many factors with intricate relationships. In this paper, the schematic diagram of structure model construction of influencing factors of the real estate housing price is drawn according to the theory of interpretative structural model (ISM). 50 real estate residential price factors were elected to build housing price factors binary relation on set and quantitative analysis matrix according to the status quo investigation and document analysis of the residential real estate prices. Interpretative structural model for residential real estate prices are constructed using standardized methods. Finally, according to the results of model housing price factors can be divided into seven levels and clear the importance of the relationship and hierarchy between the various factors. It provides a reference for the price of residential real estate management and regulation..

\section{Introduction}

Real estate development is directly related to the country's state of economic development and has a huge impact on economic development in many countries and regions. It has become a pillar industry in some areas. Real estate position in China continues to increase and the economic impact is also increasingly significant. In recent years, China's real estate market is booming. In some areas it has become a hot investment and also the national consumption of hot spots. It has become a driving engine of economic development. However, housing prices rose rapidly in some areas due to the rapid development of real estate. This phenomenon has aroused the concern and attention of majority of the people. Housing prices are not only an economic issue, but also related to people living and production aspects of social problems. So it is important to understand the factors that affect housing prices operation mechanism, and thus make effective regulations to control residential real estate prices.

Mankiw and Weil (1989) believes that lead to a generation of people in the 70s of the 20th century in the United States after World War II, the baby boomers enter marriage purchase stage is the main reason for rising U.S. housing prices in major cities of the seventies of the 20th century in the United States.[1] In addition to population factors, income is also a common factor in the housing price model. Hamilton and Schwab (1985)[2], Fortura and Kushner (1986) in Canada in 1981 established the housing price equation after the empirical research of 30 city housing prices. [3] The conclusion is that the residents' income and housing prices have a strong positive correlation between Mankiw and Weil (1989) for the first time analyzes it using a comprehensive consideration of the relationship between income and housing prices [4]. In the course of the study, scholars have come to realize that the influence of population and income on housing price is great. But they are not the only 
factors that affect housing prices. Only considering the two factors, the model cannot explain the change pattern of the housing price.

In the late 1990s, scholars began to consider the impact of economic variables on housing prices. The theoretical basis of this study is the stock flow model (Stock -Flow Model) at that time. The typical research of the stock flow model mainly includes: Case, Karl E Shiller et al (1990) made the parallel regression analysis using the main cities of the CPI, personal income, population indicators, residential construction and housing costs and other factors as the independent variable and the housing price index for the variables. It is concluded that there is a strong positive correlation between the housing price index and the independent variables.[5] Seko (2003) did the relevant research using 46 counties of Japan's income, population, price consumption index, vacancy rate data. It showed that there was a strong correlation between the Japanese housing price and economic fundamentals, such as, etc.[6] These scholars have done a lot of research on the stock flow model (-Flow Model Stock) as the theoretical basis.

Most scholars made a regression analysis on the relationship between housing price and population, economy and other factors, and concluded that the relationship between the factors and the housing price. However, the research on the interaction mechanism between the internal factors and the influencing factors is not in-depth. Each factor not only affects the housing price, but also affects each other, and through the mutual influence of the various factors affects the changes of the price of housing. Clarify the relationship between factors and hierarchy, has important significance to explain and forecast the housing price

\section{Related concepts of Interpretative Structural Modeling (ISM)}

Interpretative structural model (ISM) is the first proposed by the United States N J professor Warfield in 1973 to analyze the structure of the complex socio-economic system structure model. The basic idea is that: The influencing factors or the components of the target results are identified through a certain technology and means. After analyzing the relationship between the factors, the directed graph is drawn according to the relationship between each other. The adjacency matrix and reachable matrix of each factor are extracted according to the directed graph. It combs the relationship between the elements of the irregular and chaotic after regionalization and hierarchy of the matrix. Finally, a hierarchical structure model is decomposed into the structure.

\section{Real estate housing price factor variable}

For any constructed system $\mathrm{S}$, the system is always composed of two or more elements $\left(S_{1}, S_{2}, \mathrm{~L} S_{n}\right)$ of mutual influence and interaction. Assuming the system is composed of $\mathrm{n}$ $(n \geq 2)$ elements. Set to $\mathrm{S}$, there are:

$$
S=\left(S_{1}, S_{2}, \mathrm{~L} S_{n}\right)
$$

\subsection{The real estate prices variable factors set}

The price of real estate can be as an organic and complex structures system, factors affecting the price as the constituent elements of the price system. Get real estate price factors through the investigation of the current situation of the real estate price and its changes and influencing factors [7-12], see Table 1.

This paper selects 50 factors which affect the real estate price and $S_{1}$ as the target factor. This system consists of 51 factors. That is $n=51$. Set up a set of influencing factors:

$$
S=\left(S_{1}, S_{2}, \mathrm{~L} S_{51}\right)
$$


Table 1 influencing factors of real estate price

\begin{tabular}{|c|c|c|c|c|c|}
\hline able $^{\text {vari }}$ & influence factor & variable & influence factor & variable & influence factor \\
\hline $\mathrm{S}_{1}$ & housing prices & $\mathrm{S}_{18}$ & supporting facilities & $\mathrm{S}_{35}$ & $\begin{array}{l}\text { Property management } \\
\text { enterprise quality }\end{array}$ \\
\hline $\mathrm{S}_{2}$ & Housing quality & $\mathrm{S}_{19}$ & Greening level & $\mathrm{S}_{36}$ & $\begin{array}{l}\text { Construction enterprise } \\
\text { quality }\end{array}$ \\
\hline $\mathrm{S}_{3}$ & Human factors & $\mathrm{S}_{20}$ & Quality of labor force & $\mathrm{S}_{37}$ & $\begin{array}{l}\text { Quality of real estate } \\
\text { enterprise }\end{array}$ \\
\hline $\mathrm{S}_{4}$ & Regional factor & $\mathrm{S} 2_{1}$ & Education and welfare & $\mathrm{S}_{38}$ & Labor supply \\
\hline $\mathrm{S}_{5}$ & $\begin{array}{l}\text { Quality of property } \\
\text { management }\end{array}$ & $\mathrm{S}_{22}$ & Political stability & $\mathrm{S}_{39}$ & Rigid demand \\
\hline $\mathrm{S}_{6}$ & Housing quality & $\mathrm{S}_{23}$ & Housing demand & $\mathrm{S}_{40}$ & Improved demand \\
\hline $\mathrm{S}_{7}$ & social factors & $\mathrm{S}_{24}$ & $\begin{array}{ll}\text { Price } \quad \text { wage } & \text { and } \\
\text { employment level }\end{array}$ & $\mathrm{S}_{41}$ & economic policy \\
\hline $\mathrm{S}_{8}$ & economic factors & $\mathrm{S}_{25}$ & financial status & $\mathrm{S}_{42}$ & land policy \\
\hline $\mathrm{S}_{9}$ & administrative factor & $\mathrm{S}_{26}$ & $\begin{array}{l}\text { National income and } \\
\text { investment level }\end{array}$ & $\mathrm{S}_{43}$ & Real estate tax policy \\
\hline $\mathrm{S}_{10}$ & education & $\mathrm{S}_{27}$ & Tax burden level & $\mathrm{S}_{44}$ & geographical position \\
\hline $\mathrm{S}_{11}$ & residential location & $\mathrm{S}_{28}$ & Housing policy & $\mathrm{S}_{45}$ & $\begin{array}{l}\text { Trade area radiation } \\
\text { capability }\end{array}$ \\
\hline $\mathrm{S}_{12}$ & Commercial location & $\mathrm{S}_{29}$ & Environmental pollution & $\mathrm{S}_{46}$ & Enterprise brand value \\
\hline $\mathrm{S}_{13}$ & $\begin{array}{l}\text { Efficiency of material } \\
\text { management }\end{array}$ & $\mathrm{S}_{30}$ & Surrounding environment & $\mathrm{S}_{47}$ & population structure \\
\hline $\mathrm{S}_{14}$ & $\begin{array}{l}\text { Property management } \\
\text { personnel qualification }\end{array}$ & $\mathrm{S}_{31}$ & climatic conditions & $\mathrm{S}_{48}$ & Living facilities \\
\hline $\mathrm{S}_{15}$ & Security level & $\mathrm{S}_{32}$ & Traffic conditions & $\mathrm{S}_{49}$ & Life convenience \\
\hline $\mathrm{S}_{16}$ & Construction quality & $\mathrm{S}_{33}$ & Business center level & $\mathrm{S}_{50}$ & $\begin{array}{l}\text { Residents' disposable } \\
\text { income }\end{array}$ \\
\hline $\mathrm{S}_{17}$ & $\begin{array}{l}\text { Construction design, } \\
\text { equipment }\end{array}$ & $\mathrm{S}_{34}$ & $\begin{array}{l}\text { Distance from business } \\
\text { center }\end{array}$ & $\mathrm{S}_{51}$ & economic growth \\
\hline
\end{tabular}

\subsection{Establish a collection of binary relations}

Binary relation is the relationship $\left(\mathrm{R}_{\mathrm{ij}}\right)$ between any two factors set $\left(\mathrm{S}_{\mathrm{i}}, \mathrm{S}_{\mathrm{j}}\right)$ according to research purposes needs including the impact of the relationship, Inclusion relation, Affiliation relationship, Causal relationship etc. It can be marked $\left(S_{i} \bar{R} S_{j}\right)$ when $S_{i}$ with $S_{j}$ was no binary relation, It is denoted $\left(S_{i} R S_{j}\right)$ when there is the binary relationship between the two factors. It is denoted $\left(S_{i} \quad R^{\prime} S_{j}\right)$ when the relationship between the two is unknown. The binary relation $\mathrm{R}$ satisfies the set, called the set of binary relations. It is denoted $\mathrm{R}_{\mathrm{b}}$.

$$
\left.\mathrm{R}_{b}=\left\{\left(S_{i}, S_{j}\right) \mid S_{i} S_{j} \notin S, S_{i} R S_{j}, i, j=1,2 \mathrm{~L}, n\right\}\right\}
$$

According to the relationship between the real estate price and the influence factors of the real estate, This paper establish a collection of binary relations:

$$
R b=\left\{\begin{array}{l}
\left(S_{2}, S_{1}\right)\left(S_{3}, S_{1}\right)\left(S_{4}, S_{1}\right)\left(S_{5}, S_{2}\right)\left(S_{6}, S_{2}\right)\left(S_{7}, S_{3}\right)\left(S_{8}, S_{3}\right)\left(S_{9}, S_{8}\right)\left(S_{10}, S_{11}\right)\left(S_{11}, S_{4}\right) \\
\left(S_{12}, S_{11}\right)\left(S_{13}, S_{5}\right)\left(S_{14}, S_{5}\right)\left(S_{15}, S_{5}\right)\left(S_{16}, S_{6}\right)\left(S_{16}, S_{17}\right)\left(S_{17}, S_{16}\right)\left(S_{17}, S_{6}\right)\left(S_{18}, S_{6}\right) \\
\left(S_{19}, S_{6}\right)\left(S_{20}, S_{7}\right)\left(S_{21}, S_{7}\right)\left(S_{22}, S_{7}\right)\left(S_{23}, S_{7}\right)\left(S_{24}, S_{8}\right)\left(S_{25}, S_{8}\right)\left(S_{26}, S_{8}\right)\left(S_{27}, S_{8}\right) \\
\left(S_{28}, S_{9}\right)\left(S_{29}, S_{30}\right)\left(S_{30}, S_{29}\right)\left(S_{30}, S_{11}\right)\left(S_{31}, S_{11}\right)\left(S_{32}, S_{11}\right)\left(S_{33}, S_{12}\right)\left(S_{34}, S_{12}\right) \\
\left(S_{35}, S_{13}\right)\left(S_{35}, S_{14}\right)\left(S_{35}, S_{15}\right)\left(S_{36}, S_{16}\right)\left(S_{37}, S_{17}\right)\left(S_{37}, S_{18}\right)\left(S_{37}, S_{19}\right)\left(S_{38}, S_{20}\right) \\
\left(S_{39}, S_{23}\right)\left(S_{40}, S_{23}\right)\left(S_{41}, S_{24}\right)\left(S_{41}, S_{25}\right)\left(S_{41}, S_{26}\right)\left(S_{41}, S_{27}\right)\left(S_{42}, S_{28}\right)\left(S_{43}, S_{28}\right) \\
\left(S_{44}, S_{30}\right)\left(S_{44}, S_{31}\right)\left(S_{44}, S_{32}\right)\left(S_{45}, S_{33}\right)\left(S_{45}, S_{34}\right)\left(S_{46}, S_{36}\right)\left(S_{46}, S_{37}\right)\left(S_{47}, S_{38}\right) \\
\left(S_{47}, S_{39}\right)\left(S_{47}, S_{40}\right)\left(S_{48}, S_{44}\right)\left(S_{49}, S_{44}\right)\left(S_{50}, S_{41}\right)\left(S_{51}, S_{41}\right)
\end{array}\right\}
$$

\subsection{Drawing the directed graph of the real estate residential price factors}


This paper draw a directed graph (Figure 1) based on a collection of factors binary relations section residential real estate prices impacts. It represents the relationship between various factors and the overall architecture.

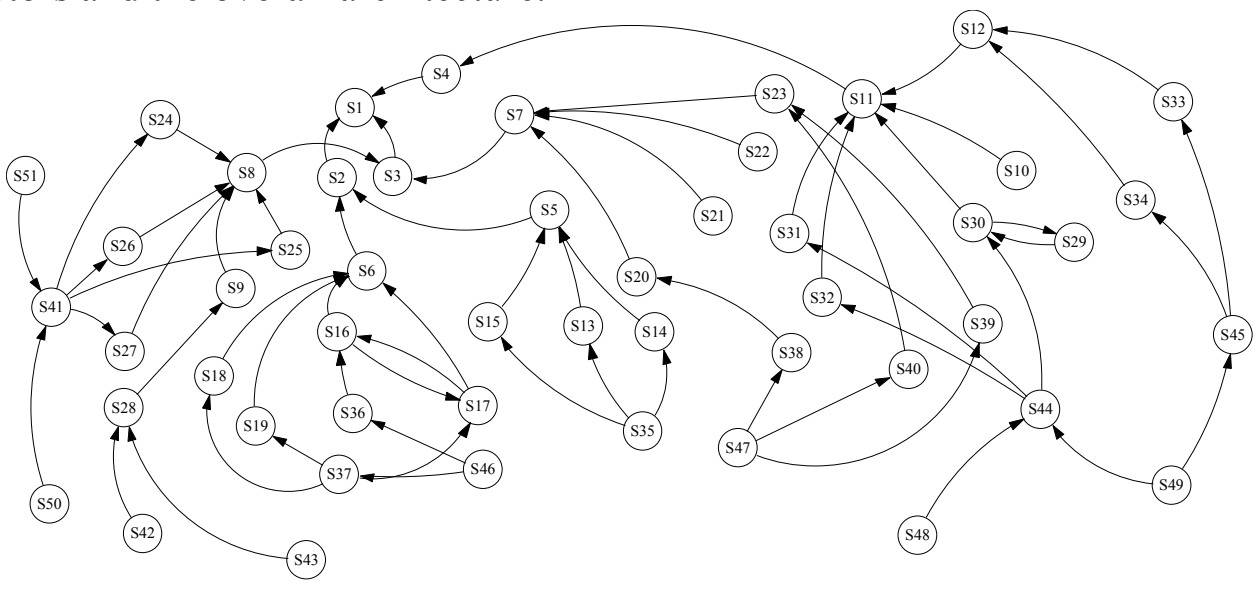

Figure. 1 Directed graph of real estate housing price influencing factors

\section{Real estate housing price influence factor matrix expression}

\subsection{The adjacency matrix of the factors influencing the price}

To quantify the relationship, it is adopted adjacency matrix, a form showing the relationship between each two of the factors.

$$
\begin{aligned}
\mathrm{A} & =\left(\mathrm{a}_{i j}\right)_{n^{*} n} \\
a_{i j} & =\left\{\begin{array}{l}
1, \\
\mathrm{SiR} S j \\
0, S i \overline{\mathrm{R}} S j
\end{array}\right\}
\end{aligned}
$$

According to equation (4) (5), the price of residential real estate factors adjacency matrix $A$ is established. A matrix of 51 row elements are all 0 , it showed factor $\mathrm{S}_{51 \mathrm{j}}$ for the system sinks element. That is the price of residential real estate. The first $21,22,35,42,43,46,47,48,49,50,51$ column elements are all 0, so called $\mathrm{S}_{\mathrm{i} 22} \mathrm{~S}_{\mathrm{i} 35} \mathrm{~S}_{\mathrm{i} 42} \mathrm{~S}_{\mathrm{i} 43} \mathrm{~S}_{\mathrm{i} 46}$ $\mathrm{S}_{\mathrm{i} 47} \mathrm{~S}_{\mathrm{i} 48} \mathrm{~S}_{\mathrm{i} 49} \mathrm{~S}_{\mathrm{i} 50} \mathrm{~S}_{\mathrm{i} 51}$ system source element. They are the fundamental elements of the real estate housing prices.

\subsection{Reachability matrix}

By explaining the structure model, the relationship between the factors affecting the price of the real estate is transitive.

$$
\left\{\begin{array}{l}
\mathrm{S}_{\mathrm{i}} \mathrm{R}_{\mathrm{j}} \\
S_{j} R S_{k}
\end{array}\right\} \Rightarrow S_{i} R S_{k}
$$

The number of transfers binary relation called the path length. Referred to as $\mathrm{R}^{\mathrm{t}}$. Through the transfer relationship interrelated factors that relationship is known as indirect relationships. When there is paths between $i$ and $j$ using $r$ times to pass through to reach: $\mathrm{M}=\left(\mathrm{m}_{\mathrm{ij}}=1\right)$; If there is no such path $\mathrm{M}=\left(\mathrm{m}_{\mathrm{ij}}=1\right)$ Use of Boolean algebra [13] can be calculated reachability matrix $\mathrm{M}$ :

$$
\mathrm{M}=(\mathrm{A}+\mathrm{I})^{\mathrm{r}}
$$

In the formula (7): I is the same order of matrix to A. Path length is calculated as follows:

$$
(A+I) \neq(A+I)^{2} \neq(A+I)^{3} \neq \mathrm{L} \neq(A+I)^{r} \neq(A+I)^{r+1} \neq \mathrm{L}(A+I)^{n}
$$

After the above steps to calculate the adjacency matrix, $(A+I)^{7}=(A+I)^{8}$. Reachable matrix is $M$.

\section{5 standardized solution of real estate price structure model \\ 5.1 residential price factors affecting regional division}


The factors that affect the price of real estate house are divided into several independent regions by S: reachable set, antecedent set, common set, initial set, termination set.

In this paper, the regional division of the influencing factors of real estate price is completed. The whole system can be divided into the following sub region:

$\left\{\mathrm{S}_{10}, \mathrm{~S}_{11}, \mathrm{~S}_{12}, \mathrm{~S}_{29}, \mathrm{~S}_{30}, \mathrm{~S}_{31}, \mathrm{~S}_{32}, \mathrm{~S}_{33}, \mathrm{~S}_{34}, \mathrm{~S}_{44}, \mathrm{~S}_{45}, \mathrm{~S}_{48}, \mathrm{~S}_{49}\right\}\left\{\mathrm{S}_{7}, \mathrm{~S}_{20}, \mathrm{~S}_{21}, \mathrm{~S}_{22}, \mathrm{~S}_{23}, \mathrm{~S}_{38}, \mathrm{~S}_{39}, \mathrm{~S}_{40}, \mathrm{~S}_{47}\right\}$

$\left.\left\{\mathrm{S}_{8}, \mathrm{~S}_{9}, \mathrm{~S}_{24}, \mathrm{~S}_{25}, \mathrm{~S}_{26}, \mathrm{~S}_{27}, \mathrm{~S}_{28}, \mathrm{~S}_{41}, \mathrm{~S}_{42}, \mathrm{~S}_{43}, \mathrm{~S}_{50}, \mathrm{~S}_{51}\right\} \mathrm{S}_{6}, \mathrm{~S}_{16}, \mathrm{~S}_{17}, \mathrm{~S}_{18}, \mathrm{~S}_{19}, \mathrm{~S}_{36}, \mathrm{~S}_{37}, \mathrm{~S}_{46}\right\}$

$\left\{\mathrm{S}_{5}, \mathrm{~S}_{13}, \mathrm{~S}_{14}, \mathrm{~S}_{15}, \mathrm{~S}_{35}\right\}$

The internal factors of the $5 \mathrm{sub}$ regions are mutually influenced and there is no relationship between the factors between the regions. The rows and columns of $\mathrm{S}_{1}, \mathrm{~S}_{2}, \mathrm{~S}_{3}, \mathrm{~S}_{4}$ in the $\mathrm{M}$ are deleted.

\subsection{Residential real estate price factors notch division}

(1) Identify the sub-region's most advanced feature to delete;

(2) identify the remaining elements of the most advanced features to remove it;

(3) Repeat the above steps until the partition to the maximum level is 1.

Results obtained as follows:

$\Pi$ P $\left.\left.1=L 1, L 2, L 3, L 4, L 5=\left\{S_{11}\right\} S_{10}, S_{12}, S_{29}, S_{30}, S_{31}, S_{32}\right\}\left\{S_{33}, S_{34}, S_{44}\right\}\left\{S_{45}, S_{48}\right\} S_{49}\right\}$

According to the same method to other sub-regions notch divided results were obtained as followed:

$$
\begin{aligned}
& \text { П Р } \left.\left.2=L 1, L 2, L 3=\left\{S_{5}\right\} S_{13}, S_{14}, S_{15}\right\} S_{35}\right\} \\
& \text { П Р } \left.\left.\left.3=L 1, L 2, L 3, L 4=\left\{S_{6}\right\} S_{16}, S_{17}, S_{18}, S_{19}\right\} S_{36}, S_{37}\right\} S_{46}\right\} \\
& \text { П Р } \left.\left.\left.4=L 1, L 2, L 3, L 4=\left\{S_{7}\right\} S_{20}, S_{21}, S_{22}, S_{23}\right\} S_{38}, S_{39} S_{40}\right\} S_{47}\right\} \\
& \text { П Р } \left.5=L 1, L 2, L 3, L 4=\left\{S_{8}\right\} S_{9}, S_{24}, S_{25}, S_{26}, S_{27}\right\}\left\{S_{28}, S_{41}\right\}\left\{S_{42} S_{43} S_{50} S_{51}\right\}
\end{aligned}
$$

According to the above notch diagonal matrix is divided into notch diagonal matrix $\mathrm{M}$ (L).

\subsection{Skeleton matrix extractor}

For notch diagonal matrix having two factors strongly connected relationship and choose to delete its rows and columns. The resulting matrix is performed detection processing. The notch diagonal matrix $M(L)$ of the skeleton of the matrix $A^{\prime}$ can establish.

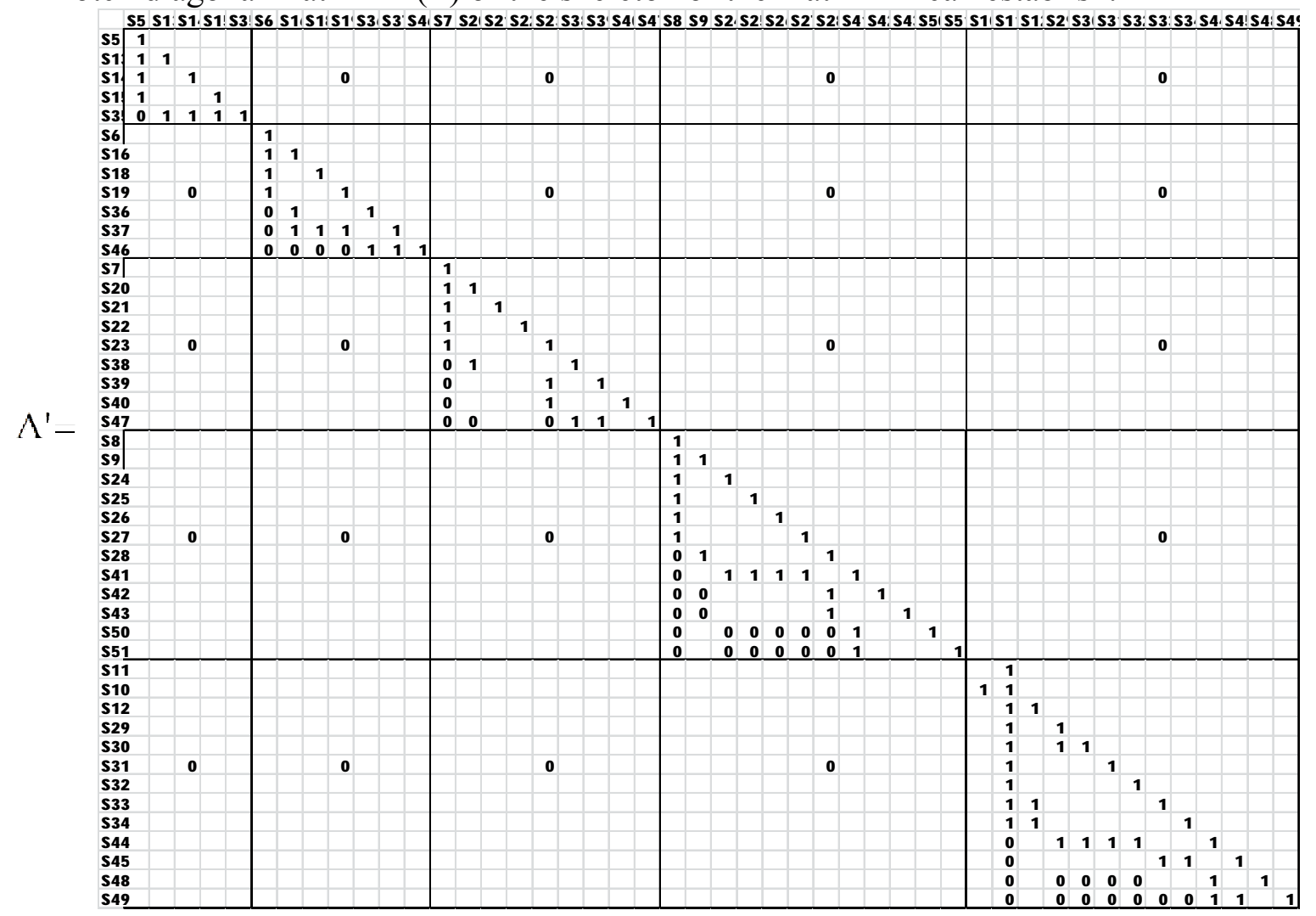




\subsection{Multi-step structure model diagram}

Based on the calculation of the matrix A', Multi-step structure model diagram ${ }^{\mathrm{D}\left(\mathrm{A}^{\prime}\right)}$ can be drawn. We get the real estate price ladder structure model.

(1) According to the regional division and the level division of $\mathrm{A}^{\prime}$, each factor is sorted from top to bottom in sequence and draw a skeleton matrix regions divide FIG notch.

(2) According to known binary relation $\mathrm{R}_{\mathrm{b}}$, there is a direct correlation between $\mathrm{S}_{5}, \mathrm{~S}_{6}$ and $\mathrm{S}_{2} ; \mathrm{S}_{7}, \mathrm{~S}_{8}$ and $\mathrm{S}_{3}, \mathrm{~S}_{4} ; \mathrm{S}_{2}, \mathrm{~S}_{3}, \mathrm{~S}_{4}$ and $\mathrm{S}_{1}$. According to the above method of dividing notch, removed elements are added to the re-division level position in FIG. Strong relationship elements being deleted during operation are also added to the division level position figure. They have to be connected by directed arcs and get the final element notch division.

(3) Elements with correlation are connected using the arcs in the Element-level bitmap. Finally hierarchical structure model ${ }^{\mathrm{D}\left(\mathrm{A}^{\prime}\right)}$ is got.

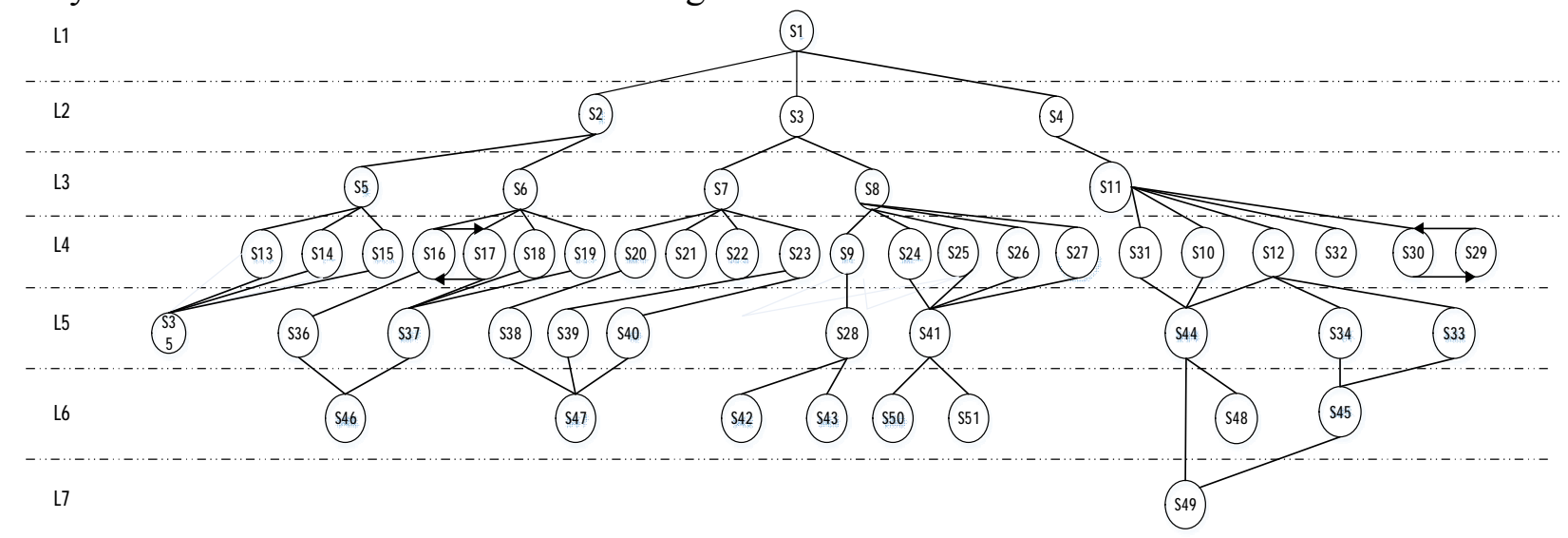

Figure. 2 Hierarchical structure model of influence factors

\section{Conclusion}

Structural model of residential real estate prices factors are obtained according to the ideological and theoretical ISM. Through investigation on real estate prices and their changes, analysing of the influencing factors, 50 factors that affect real estate prices was selected. The set of binary relations of residential real estate prices and quantitative analysis matrix were established. The matrix regionalization processes were completed with the use of standardized methods. Interpretative structural model for residential real estate prices influencing factors was finally constructed.

Research shows: the matrix was quantified with the application of interpretative structural model ISM normalization method. Finally, the hierarchical structure model, the order structure and hierarchy structure of the influencing factors of real estate housing price clearly indicates the importance of relationships between variables. The results of the model analysis showed that, property management companies, brand value, population structure, education welfare state, political stability, disposable income growth, economic growth, land policy, real estate tax policy, living facilities, convenient living and other factors are the fundamental factors affecting the residential real estate prices. They have an important impact on the price of real estate.

Interpretation structure model provides a new solution for the study of the factors affecting the price of real estate housing. It can clearly express the structural relationship between real estate price influencing factors. But this method can only estate analysis of factors from a qualitative point of view of the real estate price. If a more in-depth and quantitative analysis of the impact factors of housing prices needed, a scientific quantitative analysis method is also needed. 


\section{References:}

[1] Mankiw, N.G. and D.N. Weil, "The Baby Boom, The Baby Bust, and the Housing Market." Regional Science \& Urban Economics, 1989. 19(2): pp. 235-258.

[2] Hamilton, B.W. and R.M. Schwab, "Expected appreciation in urban housing markets." Journal of Urban Economics, 1985. 18(1): pp. 103-118.

[3] Fortura, P. and J. Kushner, "Canadian Inter-City House Price Differentials." Real Estate Economics, 1986. 14(4): pp. 525 - 536.

[4] Chen, Y., et al., "The Impact of Population Ageing on House Prices: A Micro-simulation Approach." Social Science Electronic Publishing, 2012. 59(5): pp. 523 - 542.

[5] Case, K.E. and R.J. Shiller, "Forecasting Prices and Excess Returns in the Housing Market." Real Estate Economics, 1990. 18(3): pp. 253-273.

[6] Quigley, J.M., "Real Estate Prices and Economic Cycles.” Berkeley Program on Housing \& Urban Policy Working Paper, 2002. 2(1): pp. 1--20.

[7] Tongkong, S., "Key factors influencing capital structure decision and its speed of adjustment of Thai listed real estate companies." Procedia - Social and Behavioral Sciences, 2012. 40: pp. 716-720.

[8] Cardella, E. and M.J. Seiler, "The effect of listing price strategy on real estate negotiations: An experimental study." Social Science Electronic Publishing, 2016. 52: pp. 71-90.

[9] Zhuge, C., et al., "Agent-based joint model of residential location choice and real estate price for land use and transport model." Computers Environment \& Urban Systems, 2016. 57: pp. 93-105.

[10] Grum, B. and D.K. Govekar, "Influence of Macroeconomic Factors on Prices of Real Estate in Various Cultural Environments: Case of Slovenia, Greece, France, Poland and Norway." Procedia Economics and Finance, 2016. 39: pp. 597-604.

[11]Jiang, L., P.C.B. Phillips and J. Yu, "New methodology for constructing real estate price indices applied to the Singapore residential market." Journal of Banking \& Finance, 2015. 61, Supplement 2: pp. S121-S131.

[12] Walker, C.B., "The direction of media influence: Real-estate news and the stock market." Journal of Behavioral \& Experimental Finance, 2016. 10: pp. 20-31.

[13] Vedam, R., "Boolean Arithmetic Polynomials and Equivalence Checking." Lecture Notes in Electrical Engineering, 2014. 248: pp. 757-767. 